\title{
Efficacy of existing antimalarial drugs for uncomplicated malaria in Timika, Papua, Indonesia
}

\author{
H Siswantoro ${ }^{*}$, A Ratcliff $^{f}$, E Kenangalem $^{\S, \infty, \phi}$, M Wuwung $^{\dagger}$, R Maristela $^{\ddagger, \phi}$, R Rumaseuw $^{\dagger, \dagger}$, F Laihad $^{\psi}$,

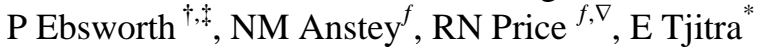

\begin{abstract}
Abstrak
Resisten klorokuin merupakan masalah penanggulangan malaria di Indonesia, terutama di Papua. Dalam rangka menilai efikasi pengobatan malaria yang tersedia di Timika, Papua, telah dilakukan uji pengobatan klorokuin dan atau tanpa sulfadoksinpirimetamin. Pasien dengan malaria Plasmodium falciparum, P. vivax, P. ovale atau P. malariae tanpa komplikasi diikutkan dalam studi dan diberikan obat klorokuin plus sulfadoksin-pirimetamin (malaria falsiparum) atau klorokuin (malaria non-falsiparum) dengan pengawasan minum obat. Selanjutnya pasien dipantau selama 28 sampai 42 hari. Pasien yang tidak sembuh akan diobati ulang dengan kina dan atau tanpa doksisiklin. Sebanyak 207 pasien diikutkan dalam studi (88 P. falciparum, 40 P. vivax, 15 campuran P. falciparum dan P. vivax, 50 P. malariae dan 14 P. ovale). Kegagalan pengobatan dini ditemukan 4 dari 86 pasien (5\%) dengan malaria falciparum, 6 dari 37 pasien (16\%) dengan malaria vivaks dan tidak dijumpai pada jenis infeksi yang lainnya. Kegagalan pengobatan pada hari ke-28 untuk P. vivax sebanyak 22 dari 30 pasien (73\%) dengan konsentrasi klorokuin dalam plasma lebih tinggi dari konsentrasi efektif minimal (Minimum Effective Concentration/MEC>15ng/ml). Setelah dikoreksi dari adanya infeksi yang baru, angka kegagalan pengobatan kasep pada hari ke-42 untuk malaria falciparum 48\%[95\%:CI 31-65] dan 61\% di antaranya dengan konsentrasi klorokuin lebih dari 30ng/ml. Pasien yang tidak sembuh diberikan pengobatan ulang dengan kina dan atau tanpa doksisiklin tanpa pengawasan minum obat. Angka kegagalan pengobatan ulang tersebut sebesar 48\%[95\%CI:31-65] pada infeksi P. falciparum dan 70\%[95CI:37-100] pada infeksi P. vivax. Kegagalan pengobatan tidak ditemukan pada infeksi P. malariae atau P. ovale dengan species yang sama setelah dipantau selama 28 hari. Di Papua, terdapat prevalensi resistensi obat yang tinggi untuk malaria P. falciparum dan P. vivax dengan pengobatan yang tersedia (klorokuin dan sulfadoksin-pirimetamin). Klorokuin masih memiliki efikasi yang baik pada P. ovale dan P. malariae. (Med J Indones 2006; 15:251-8)
\end{abstract}

\begin{abstract}
Chloroquine resistant malaria is a serious problem in Indonesia particularly in Papua. A trial of the existing antimalarial drugs was conducted in Timika, Papua. The objective of the study was to determine the efficacy of cloroquine (CQ) \pm sulfadoxine-pyrimethamine (SP). Patients with uncomplicated malaria due to Plasmodium falciparum, P. vivax, $P$. ovale or P. malariae were enrolled and treated with supervised $C Q+S P$ ( $P$. falciparum) or $C Q$ (non-P. falciparum). Patients were followed for $28-42$ days. Patients failing therapy were retreated with unsupervised quinine \pm doxycycline. 207 patients were enrolled in the study (88 P. falciparum, 40 P. vivax, 15 mixed infections, 50 P. malariae and 14 P. ovale). Early treatment failures occurred in 4 of 86 (5\%) patients with falciparum malaria, 6 of $37(16 \%)$ patients with vivax malaria and none of those with P. ovale or P. malariae infections. The failure rate by day 28 for $P$. vivax was 22 of 30 (73\%) patients, with all recurrences occurring in the presence of plasma chloroquine concentration above the minimum effective concentration $(M E C>15 \mathrm{ng} / \mathrm{ml})$. After correcting for reinfections the day 42 recrudescence rate for falciparum malaria was 48\% [95\% CI:31-65] and in 61\% of cases this was in the presence of chloroquine levels above $30 \mathrm{ng} / \mathrm{ml}$. Retreatment with unsupervised quinine \pm doxycycline resulted in further recurrence of malaria in 48\% [95\%CI:31-65] of P. falciparum infections and 70\% [95\%CI:37-100] of P. vivax infections. None of the patients with P. ovale or P. malariae had treatment failures within 28 days. There is a high prevalence of antimalarial drug resistance of $P$. falciparum and $P$. vivax to the existing antimalarial drugs. However chloroquine retains adequate efficacy against $P$. ovale and P. malariae in Papua. (Med J Indones 2006; 15:251-8)
\end{abstract}

Keywords: Malaria, P. falciparum, P. vivax, P. ovale, P. malariae, Chloroquine, Sulfadoxine-pyrimethamine, Papua

\footnotetext{
* National Institute of Health Research and Development (NIHRD), Jakarta, Indonesia

${ }^{f}$ Int'l Health Program, Menzies School of Health Research (MSHR) and CDU, Darwin, Northern Territory, Australia

$\S$ MSHR-NIHRD Malaria Research Program, Timika, Indonesia

${ }^{\infty}$ Dinas Kesehatan Kabupaten Mimika, Timika, Papua, Indonesia

${ }^{\dagger}$ Public Health \& Malaria Control Department, PT Freeport Indonesia, Tembagapura, Papua, Indonesia

International SOS, Tembagapura, Papua, Indonesia

${ }^{\phi}$ Lembaga Pengembangan Masyarakat Amungme Kamoro, Timika, Papua, Indonesia

${ }^{\psi}$ Directorate General of Disease Control and Environment Health, Ministry of Health, Jakarta, Indonesia
} 
Since the 1950s, chloroquine has been the most extensively used antimalarial for uncomplicated malaria. It has the advantage of being widely available, cheap, well tolerated and safe. ${ }^{1}$ Drug resistant strains of P. falciparum first emerged in Cambodia in $1959^{2,3}$ and subsequently spread throughout Asia and Africa. Resistance of $P$. falciparum to chloroquine therapy was first noted in Indonesia almost 30 years ago, ${ }^{4}$ and has now been documented through out the country ${ }^{5-7}$ with the highest prevalence reported from northern Papua. ${ }^{8}$ Declining efficacy has also been noted to the second therapy of sulfadoxine-pyrimethamine (SP). ${ }^{9,10}$

The emergence of drug resistant strains of $P$. vivax was only described in 1989 in northern Papua province (formerly Irian Jaya). ${ }^{11}$ Other studies of $P$. vivax have subsequently confirmed a high prevalence of chloroquine resistance in Sumatra, and Northern Papua ${ }^{8-10}$ and elsewhere in Indonesia. ${ }^{12}$ Resistance to SP has also been noted. ${ }^{9}$

$P$. ovale and P. malariae account a minor number of cases of malaria, although in some regions their prevalence in symptomatic patients can reach as high as $10 \% .^{5}$ Few studies have addressed the efficacy of chloroquine to these strains. A recent study in South Sumatra did however indicate the resistant strains of P. malariae may be emerging. ${ }^{7}$

In Mimika district on the Southern part of Papua, malaria transmission is unstable and causes an appreciable burden of disease despite an extensive malaria control programme. A small unpublished study in 2001 reported that the day 28 cure rate for $P$. falciparum had fallen to $21 \%$ following sulfadoxinepyrimethamine alone and 25\% for chloroquine plus sulphadoxine-pyrimethamine (Crouch-Chivers, personal communication). Failure rates of chloroquine monotherapy for vivax malaria in Timika are unknown, however in the same study chloroquine three days plus a single dose of sulfadoxine-pyrimethamine and primaquine on day 0 resulted in a day 28 cure rate of $25 \%$.

As part of a series of studies to rationalize antimalarial protocols in this region we undertook a series of chemotherapeutic trials to evaluate and to determine the efficacy of prevailing protocols for uncomplicated malaria.

\section{MATERIALS AND METHODS}

\section{Study Site}

The study was carried out at an established rural outpatient clinic west of Timika town in Southern Papua (formerly Irian Jaya), Indonesia. This forested lowland area has unstable malaria transmission associated with three mosquito vectors: Anopheles koliensis, An. farauti and An. Punctulatus. ${ }^{13,14}$ The annual incidence of malaria is 620 per 1000 per year, divided 55:45 between $P$. falciparum and $P$. vivax infections. In recent surveys of healthy school children the prevalence rate for P. falciparum was 3.3\% (203/6173) and that of P. vivax 2.9\% (177/6173) - (Peter Ebsworth, personal communication). Due to economic migration the ethnic origin of the local population is diverse, with highland Papuans, lowland Papuans and non Papuans all resident in the region. In view of the high number of infections in non immune patients, local protocols recommend that all patients with patent parasitaemia be given antimalarial therapy irrespective of whether they have symptoms or not.

\section{Study Design}

This was a prospective open label without randomization drug efficacy study of existing drugs recommended in 2004 for infections with $P$. falciparum (chloroquine with sulfadoxine-pyrimethamine), P. vivax (chloroquine), $P$. ovale (chloroquine) or P. malariae (chloroquine) in children and adults with uncomplicated symptomatic malaria. The study was based on the 2003 World Health Organization (WHO) in vivo antimalarial drug sensitivity protocol, ${ }^{15}$ modified to include mixed infections. Patients were followed for 42 days in the falciparum malaria and 28 days for other species of infection.

\section{Patients}

Consecutive patients with slide-confirmed malaria of any species and fever or a history of fever during the preceding 48 hours presenting to the outpatient clinic were enrolled in the study if they or their parents gave informed consent. Pregnant or lactating women, children under $10 \mathrm{~kg}$, patients with signs of severity, ${ }^{16}$ a parasitaemia $>4 \%$, or concomitant disease requiring hospital admission were all excluded. Informed consent was given by an adult patient or by a parent/guardian 
for children. If the subject was illiterate, consent was obtained in the presence of a literate witness. All patients were given an information sheet in their own language.

\section{Study Procedures}

On admission a standardized questionnaire was completed recording demographic information and details of symptoms and their duration and the history of previous antimalarial medication. A full clinical examination was made and the axillary temperature measured using a digital electronic thermometer. Blood was taken for blood film, haematocrit, and white cell count. Parasite counts were determined on Giemsa-stained thick films as the number of parasites per 200 white blood cells (WBC). All slides were read by a certified microscopist with 10 years experience. A thick smear was considered negative on initial review if no parasites were seen in 100 high power fields. A thin smear was also examined to confirm parasite species and used for quantification if parasitaemia was greater than 200 per $200 \mathrm{WBC}$. All slides were cross checked by another experienced microscopist. Upon cross checking the whole field was checked before a slide was considered negative.

All patients were examined daily thereafter until they became afebrile and aparasitaemic. At each visit a blood smear was taken and a symptom questionnaire completed. Patients were then seen weekly or on any other day when the patient was sick for 4 weeks (P. vivax, Povale, P. malariae infections) or 6 weeks (P. falciparum or mixed infections). At each clinic appointment a full physical examination was performed, the symptom questionnaire was completed, and blood was taken to check for parasite count and haemoglobin level using a battery operated portable photometer (HemoCue Hb201+ TM). Blood spots on filter paper (Whatman 3MM Chromatography Paper) were also collected on day 0 and the day of failure, therefore we can distinguish between reinfection and recrudescence infection with the polymerase chain reaction $(\mathrm{PCR})$.

\section{Plasma Chloroquine Levels}

Heparinized venous blood samples were taken from patients who agreed to be venesected on days $0,7,28$ or the day of recrudescence. Samples were processed within 4 hours of venesection, spun at $2000 \mathrm{rpm}$ for 10 minutes and plasma removed and stored at $-20^{\circ} \mathrm{C}$ until analysed. Plasma drug levels of chloroquine (CQ) and its major metabolite desethylchloroquine (DCQ) were assayed by high performance liquid chromatography as described previously. The minimum effective concentration (MEC) of chloroquine plus desethylchloroquine (CQ+DCQ) for P. falciparum was defined as $30 \mathrm{ng} / \mathrm{ml}$ plasma and $15 \mathrm{ng} / \mathrm{ml}$ for $P$. vivax. ${ }^{17}$

\section{Treatment}

Standard treatment courses of CQ+SP for P. falciparum (alone or mixed with $P$. vivax), and CQ for pure $P$. vivax, $P$. ovale or $P$. malariae infections were administered. The CQ+SP regimen consisted of CQ (CQ: P.T Bayer, Jakarta, Indonesia-150 mg base/tablet, 25 $\mathrm{mg} / \mathrm{kg}$ over 3 days) and SP was given as a single dose on day 0 (25 and $1.25 \mathrm{mg} / \mathrm{kg}$, respectively). All drug administrations were supervised and participants observed for 30-60 minutes to exclude adverse reactions and to ensure the medication was not vomited out. If vomiting occurred within 60 minutes the whole dose was repeated once. If vomiting occurred again within 60 minutes the patient was withdrawn from the study. If the axillary temperature was $\geq 38^{\circ} \mathrm{C}$, paracetamol was given.

Treatment failures were retreated with quinine $(10 \mathrm{mg}$ of salt $/ \mathrm{kg}$ body weight/dosage orally 3 times a day for 7 days) plus doxycycline (100 mg bd for 7 days) if $\geq 8$ years age and not pregnant. From May 2004 those patients with reappearance of $P$. vivax within 28 days were given a 3 day course of supervised amodiaquine if they consented (Flavoquine ${ }^{\mathrm{TM}}$ : Aventis $-153 \mathrm{mg}$ base /tablet, $30 \mathrm{mg} / \mathrm{kg}$ over 3 days). Primaquine ( $0.5 \mathrm{mg}$ of base $/ \mathrm{kg}$ of body weight for 14 days) was administered to those individuals with $P$. vivax or $P$. ovale infection or mixed infection on day 28 of their participation in the study.

\section{Endpoints}

Therapeutic response was determined using clinical and parasitological criteria. The primary endpoints were the therapeutic response on the basis of parasitological and clinical cure by day 28 for $P$. vivax, $P$. ovale or $P$. malariae infections and day 42 for $P$. falciparum infection. The criteria, based on 2003 WHO protocol, ${ }^{15}$ were modified to include $P$. falciparum genotyping to differentiate recrudescence from reinfection. The latter was distinguished according to polymorphisms in Merozoite Surface Proteins-1 (MSP-1), Merozoite Surface Proteins-2 
(MSP-2) and Glutamaterich Protein (GLURP), before and after antimalarial drug treatment. ${ }^{18}$ New infections detected by genotyping were classified as nontreatment failures. New infections and indeterminant Polymerase Chain Reaction (PCR) results were excluded from the day 28 or 42 failure rate if the follow up was terminated before endpoint was achieved. Since chloroquine concentrations persist at levels above the MEC for $P$. vivax beyond 28 days, ${ }^{19}$ any recurrence within this time were considered to be therapeutic failures.

\section{Statistical analysis}

Data were analysed using SPSS for Windows (SPSS Inc, Chicago, Illinois). The Mann-Whitney U test or Kruskal-Wallis method was used for nonparametric comparisons, and Student's t-test or one-way analysis of variance for parametric comparisons. For categorical variables percentages and corresponding 95\% confidence intervals $(95 \% \mathrm{CI})$ were calculated using Wilson's method. Proportions were examined using $\chi^{2}$ with Yates' correction or by Fisher's exact test.

\section{Ethics}

The study was approved by the Ethics Committee of the National Institute of Health Research and Development, the Indonesian Ministry of Health (Jakarta, Indonesia), the Ethics committee of Menzies School of Health
Research (Darwin, Australia). Informed consent was obtained from all adult participants and from parents of children.

\section{RESULTS}

Between April 2004 and August 2005, 207 patients were enrolled in the study. Of these 103 patients were infected with $P$. falciparum $(\mathrm{n}=88)$ or $P$. falciparum and $P$. vivax infections $(\mathrm{n}=15)$ and treated with chloroquine plus sulfadoxine-pyrimethamine (CQ+SP). The remaining 104 patients were infected with single species infections $(P$. vivax $\mathrm{n}=40, P$. malariae $\mathrm{n}=50$, $P$. ovale $\mathrm{n}=14)$ and were treated with chloroquine monotherapy. Baseline characteristics are given in table 1 .

\section{Demographics Details}

Patients with $P$. vivax or mixed infections of $P$. falciparum / P. vivax were significantly younger with $27 \%$ (15 of 55) being under 5 years of age compared to 9\% (14 of 152) of those with other species of infection (see table 1). Conversely the geometric mean parasitaemia on admission in those patients infected with $P$. falciparum either alone or mixed was $1851 \mathrm{ul}^{-1}$ [95\% CI: 1241-2761], significantly higher than those patients with non falciparum malaria $\left(640 \mathrm{ul}^{-1}\right.$ [95\%CI: 497824]; $\mathrm{p}<0.001)$.

Table 1. Baseline characteristics of uncomplicated malaria study patients

\begin{tabular}{|c|c|c|c|c|c|c|}
\hline \multirow{2}{*}{\multicolumn{2}{|c|}{ Species }} & \multicolumn{2}{|c|}{ Chloroquine + Sulfadoxine-Pyrimetamine } & \multicolumn{3}{|c|}{ Chloroquine Monotherapy } \\
\hline & & P. falciparum & Mixed Infections & P. vivax & P. malariae & P. ovale \\
\hline \multicolumn{2}{|c|}{ No. of Subjects Enrolled } & 88 & 15 & 40 & 50 & 14 \\
\hline \multicolumn{2}{|c|}{ Males $\quad \mathrm{N}(\%)$} & $64 \%(56)$ & $47 \%(7)$ & $55 \%(22)$ & $62 \%(31)$ & $64 \%(9)$ \\
\hline \multicolumn{2}{|l|}{ Papuan } & $56 \%(49)$ & $67 \%(10)$ & $65 \%(26)$ & $76 \%(38)$ & $79 \%(11)$ \\
\hline \multicolumn{2}{|c|}{ Age Median (range) in years } & $17.5(1-60)$ & $10(4-60)$ & $15(1.8-60)$ & $15.5(2-49)$ & $29(3-53)$ \\
\hline Age $<5$ & $\mathrm{~N}(\%)$ & $9 \%(8)$ & $27 \%(4)$ & $28 \%(11)$ & $10 \%(5)$ & $7 \%(1)$ \\
\hline Age 5-14 & $\mathrm{N}(\%)$ & $36 \%(32)$ & $27 \%(4)$ & $23 \%(9)$ & $38 \%(19)$ & $14 \%(2)$ \\
\hline Age $>14$ & $\mathrm{~N}(\%)$ & $55 \%(48)$ & $47 \%(7)$ & $50 \%(20)$ & $52 \%(26)$ & $79 \%(11)$ \\
\hline \multicolumn{2}{|c|}{ Temperature $\left({ }^{\circ} \mathrm{C}\right)>37.5^{\circ} \mathrm{C} \quad \mathrm{N}(\%)$} & $35 \%(31)$ & $33 \%(5)$ & $15 \%(6)$ & $14 \%(7)$ & $14 \%(2)$ \\
\hline \multicolumn{2}{|c|}{ Haemoglobin (g/dl) Mean (SD) } & $10.2 \pm 1.9$ & $9.8 \pm 2.2$ & $10.5 \pm 2.1$ & $9.5 \pm 2.1$ & $12,1 \pm 3.0$ \\
\hline $\mathrm{HB}<10$ & $\mathrm{~N}(\%)$ & $44 \%(39)$ & $47 \%(7)$ & $38 \%(15)$ & $68 \%(34)$ & $36 \%(5)$ \\
\hline \multicolumn{2}{|c|}{$\begin{array}{l}\text { Geometric Mean }(95 \% \mathrm{CI}) \text { parasite } \\
\text { count per } \mu \text { l blood }\end{array}$} & 1651(1071-2547) & $3618(1206-10,885)$ & $578(340-992)$ & $646(493-847)$ & 791(354-1770) \\
\hline \multicolumn{2}{|c|}{ Gametocyte carriage (\%) } & $8 \%(7)$ & $40 \%(6)$ & $13 \%(5)$ & $28 \%(14)$ & $43 \%(6)$ \\
\hline \multicolumn{2}{|c|}{ Splenomegaly } & $37 \%(31 / 85)$ & $27 \%(10)$ & $39 \%(15 / 39)$ & $38 \%(19)$ & $36 \%(5)$ \\
\hline
\end{tabular}


Overall $7 \%$ (15 of 207) of patients failed to comply with a full course of therapy and 5\% (11 of 207) had recurrent vomiting requiring rescue therapy. There was no difference in these proportions between treatment groups (see figure 1). Of the 181 patients who received a full treatment course, the mean dose of chloroquine administered was $27.0 \mathrm{mg} / \mathrm{kg}$ [SD $3.0 \mathrm{mg}$ ]. Follow up to day 28 or day of failure in these patients was achieved in $86 \%$ (156 of 181) following drug administration.

\section{Tolerability}

Overall vomiting of the first dose of chloroquine within an hour of administration occurred in 6.8\% (14 of 207) of patients and did not differ between species of infection or co-administration of SP. Vomiting any dose of chloroquine occurred in $16 \%$ of children (15 of 95) compared to $1.8 \%$ (2 of 112) in adults.

\section{Early Therapeutic Response}

Early parasitological failure was observed in 10 patients: 3 with $P$. falciparum, 6 with $P$. vivax and one mixed infection. Four patients developed warning signs or markers of severity and required rescue with intravenous quinine. One adult with $P$. falciparum developed convulsions and coma and a child with falciparum malaria developed respiratory distress on day one. An adult and a child, both were with vivax malaria, developed severe vomiting and diarrhea on day one. The remaining six patients received oral quinine and all made a complete recovery.

Parasite clearance was delayed following treatment of $P$. vivax (either alone or mixed with $P$. falciparum) with $32 \%$ (13 of 41) still parasitaemic by day 3 . This was significantly longer compared to only $7 \%$ (4 of 58 ) in those with pure falciparum infection ( $\mathrm{RR}=4.6$ [95\%CI: 1.6-13], $\mathrm{p}=0.003)$ and 1 of $52(2 \%)$ of those with either $P$. malariae or $P$. ovale $(\mathrm{RR}=16.5$ [95\%CI:2.3-120.9], $\mathrm{p}=0.0002$ ).

Although all patients presented with a history of fever, only $25 \%$ (51 of 207) actually had a recorded fever on admission. Patients with $P$. falciparum (alone or mixed) were at significantly greater risk of fever compared to non falciparum malaria. Of those patients presenting with a fever $94 \%$ (33 of 35) had defervesced by day 2 .

\section{Late Therapeutic Response}

Recurrence of infection during recovery was observed in 88 patients: 48 of whom had $P$. falciparum, 29 had $P$. vivax and 11 had mixed infections (figure 1 ).

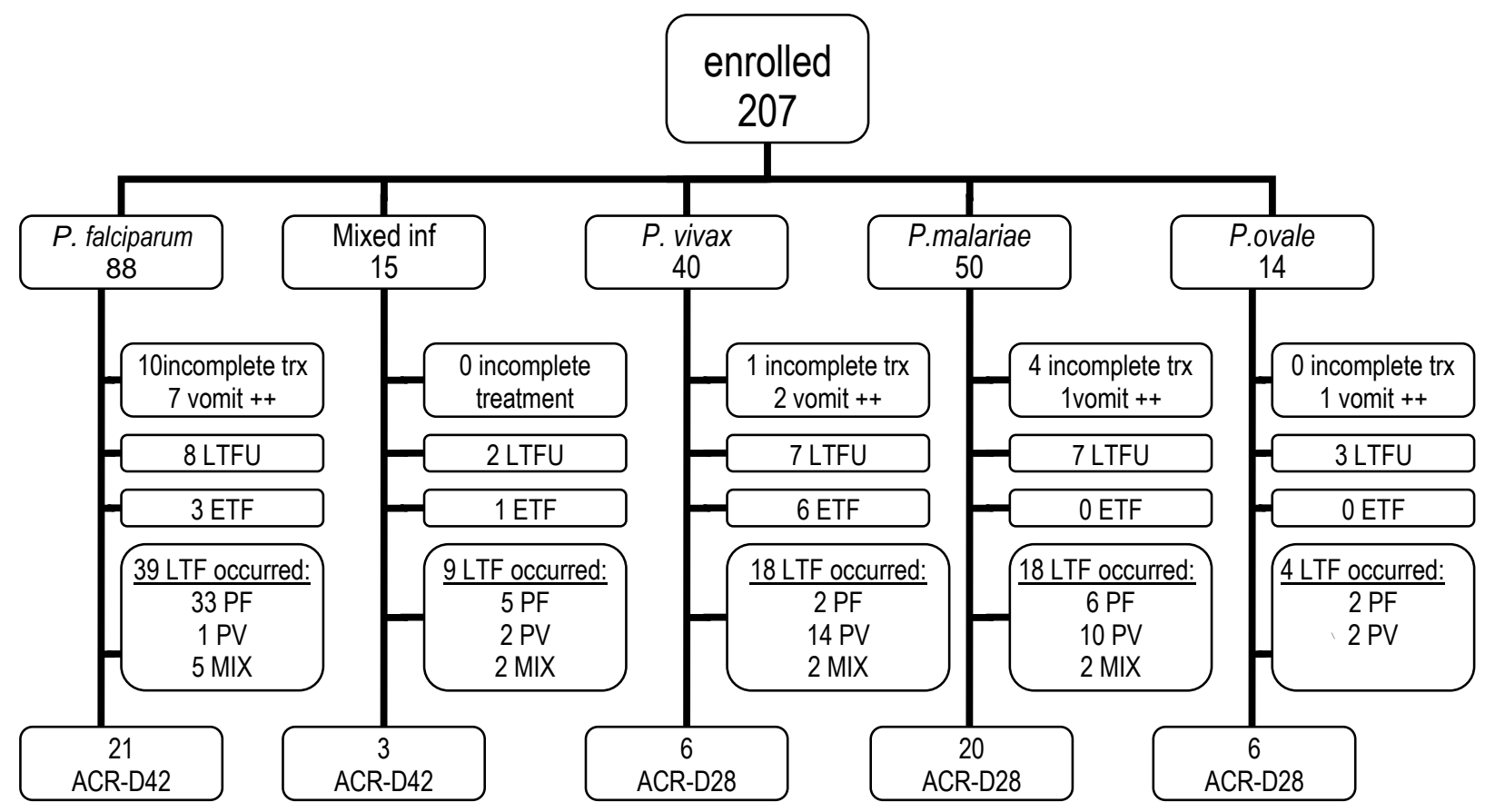

Figure 1. The flowchart of patients enrolled in existing therapies study 
Tabel 2. Late therapeutic efficacy of standard therapies: Chloroquine plus SP for falciparum malaria and chloroquine monotherapy for non falciparum malaria

\begin{tabular}{llllll}
\hline & P. Falciparum & $\begin{array}{c}\text { Mixed } \\
\text { infections }\end{array}$ & P. Vivax & P. Malaria ${ }^{\ddagger}$ & P. Ovale \\
\hline Failure rate on day 7 & $16 \%(11 / 69)$ & $13 \%(2 / 15)$ & $28 \%(10 / 36)$ & $0 \%(0 / 42)$ & $0 \%(0 / 13)$ \\
Failure rate on day 28 & $59 \%(37 / 63)^{*}$ & $77 \%(10 / 13)^{\wedge}$ & $73 \%(22 / 30) \#$ & $0 \%(0 / 27)^{* *}$ & $0 \%(0 / 8)^{\wedge \wedge}$ \\
$\begin{array}{l}\text { Failure rate on day } 42 \\
\text { Time to Recrudescence }\end{array}$ & $73 \%(41 / 56)^{*}$ & $77 \%(10 / 13)^{\wedge}$ & - & - & - \\
Days Median (range) & $16(7-24)$ & $15(7-24)$ & $12(1-22)$ & & \\
\hline
\end{tabular}

* Reappearance of falciparum or mixed infections. ^ Reappearance of either falciparum or vivax malaria.

${ }^{\#}$ Reappearance of vivax or mixed infections. ${ }^{* *}$ Reappearance of malariae malaria. ${ }^{\wedge}$ Reappearance of ovale malaria.

Overall failure rates were defined as either early treatment failure or the recurrence of the same species after treatment (either alone or mixed). Failure rates after $P$. falciparum and $P$. vivax infections were high (table 3). By day $4273 \%$ (41 of 56) of pure P. falciparum and $77 \%$ (10 of 13) of mixed infections had failed treatment. $P$. vivax infections were followed up for 28 days prior to administration of primaquine. By this time $73 \%$ (22 of 30) had failed therapy. Although recurrence of $P$. falciparum and $P$. vivax occurred in $34 \%$ (22 of 64) with $P$. malariae or $P$. ovale infections, there was no occurrence of treatment failure with the same species.

Parasite genotyping was successful and informative in $70 \%$ (24 of 41) of the late P. falciparum or mixed isolates and identified 19 true recrudescence and 10 new infections, with indeterminate results in 21 cases. Therefore the polymerase chain reaction (PCR) corrected cure rate of $P$. falciparum by day 42 was $48 \%$ [95\% CI :36-66].

\section{Chloroquine levels}

On admission plasma chloroquine levels were available in 89 patients of whom 39\% (35 of 89) patients had chloroquine detected. At the time of recrudescence of P. falciparum or P. vivax $83 \%$ (25 of 30) of those tested had detectable chloroquine concentrations in their blood (median= $82.0 \mathrm{ng} / \mathrm{ml}$ [range: $10-242]$ ). Of these patients $61 \%$ (14 of 23 ) of those with $P$. falciparum had plasma levels above the MEC (30 $\mathrm{ng} / \mathrm{ml}$ ) and $100 \%$ (7 of 7) of those with $P$. vivax had plasma levels above the MEC $(15 \mathrm{ng} / \mathrm{ml})$.

\section{Gametocyte Carriage and Anaemia}

On admission gametocytes were present in 26\% (31 of 119) of non falciparum malaria compared to only
$8 \%$ (7 of 88) of patients with pure falciparum malaria (table $1, \mathrm{p}=0.001$ ). However during follow up only $0.8 \%$ (1 of 119) of patients infected with non falciparum malaria had patent gametocytaemia, compared to $46 \%$ (32 of 70) after falciparum malaria on day 7 and $45 \%$ (24 of 53) on day 14.

On the day of admission anemia (HB under $10 \mathrm{~g} / \mathrm{dl}$ ) were present in $48 \%$ (100 of 207) of patients. Patients with $P$. malariae were at higher risk of anaemia compared to those with other species $(\mathrm{p}=0.001)$. Furthermore patients who failed therapy were 2.2 fold [95\%CI 1.1-4.3] more likely to be anaemic on day 7 irrespective of initial species $(\mathrm{p}=0.03)$.

\section{Re-treatments}

Overall 52 patients had $P$. falciparum or mixed infections detected during follow up requiring retreatment, of whom 24 (46\%) adults and 28 (54\%) children (less than 14) agreed to be reenrolled for further follow up. Adults received an unsupervised 7 day course of quinine plus doxycycline, however by day $2857 \%$ (8 of 14) had had a further recurrence of $P$. falciparum. Children were retreated with 7 days unsupervised quinine and by day 28, 76\% (19 of 25) had failed therapy again.

Of the 20 patients with $P$. vivax infection during follow up, 12 patients were treated with supervised amodiaquine and 6 patients with unsupervised quinine. Only 8 were successfully followed to day 28 after treatment: 3 following amodiaquine and 5 following quinine therapy. There were four further treatment failures, 3 after quinine and 1 after amodiaquine. 


\section{DISCUSSION}

Since 2004, the combination of artesunate-amodiaquine has become the drug of choice for uncomplicated malaria in Indonesia. However, prior to policy change the majority of uncomplicated infections were still treated with chloroquine (CQ) in Timika, Papua. We therefore evaluated the therapeutic efficacy of the existing antimalarial drugs in symptomatic patients with uncomplicated falciparum and vivax malaria in Timika using the 1997 WHO guidelines. Patients were treated with chloroquine and sulfadoxine-pyrimethamine (SP) for uncomplicated malaria falsiparum and followed for 42 days. Patients with uncomplicated malaria due to other species ( $P$. vivax, $P$. ovale, or P. malariae) were given chloroquine monotherapy and followed for 28 days before receiving a 14 day course of unsupervised primaquine (P.vivax or P.ovale). Patients failing therapy received unsupervised oral quinine +/doxycycline for 7 days.

During the execution of this study, we were also able to evaluate the efficacy of amodiaquine in a relatively small number of patients with reappearance of uncomplicated vivax malaria.

In this rural area uncomplicated malaria was observed more in males $(60 \%)$ and in Papuan $(65 \%)$ people. This may reflect the greater exposure of adult males and non Papuans to areas of malaria transmission. Symptomatic malaria occurred in all age groups in keeping with the high proportion of non immune individuals in this area.

The cumulative day 28 failure rate for P.falciparum was $59 \%$ compared to and $77 \%$ for pure vivax infections. After correcting for reinfection by PCR the day 42 failure rate for $P$. falciparum was $62 \%$ [95\% CI: 47-74]. These high rates of late treatment failure were associated with extremely poor early therapeutic response with $4 \%$ of patients with falciparum malaria and $16 \%$ of patients with $P$. vivax requiring rescue therapy. Retreatment with an unsupervised course of quinine +/- doxycycline was associated with an equally poor outcome. By day $28,57 \%$ of patients with a recurrence parasitaemia retreated with quinine plus doxycycline failed therapy again and this figure rose $76 \%$ in children who were treated with quinine alone. Quinine treatment was unsupervised and although the poor efficacy could be attributable to quinine resistance a more likely explanation is poor adherence to a difficult regimen (three times daily for 7 days) which is frequently associated with unpleasant side effect (cinchonism, nausea and dizziness ). Although a study of supervised therapy would help to resolve this, in practice supervision is not an option and hence the usefulness of this regimen appears limited in uncomplicated malaria.

In total 11 patients with recrudescent $P$. vivax were retreated with amodiaquine monotherapy. Early parasite clearance was rapid in all cases with no early treatment failures. Although only three patients were followed for 28 days no failure of therapy was found during this time. This is one of the first reports of the efficacy of amodiaquine against chloroquine-resistant strains. Although it suggests that its efficacy may be superior to chloroquine, further studies are needed to confirm this.

In contrast to the poor efficacy of $P$. falciparum and $P$. vivax there were no early treatment failures when chloroquine was used alone for $P$. malariae malaria or $P$. ovale infections. Although late treatment failures did occur (18 following $P$. malariae and 6 following $P$. ovale), none of these were with the same species, suggesting either reinfection or recrudescence from pre-patent parasitaemias in the initial infection. Hence the success rate of either of these species to chloroquine remains at $100 \%$.

Alternative treatment regimens in this region are clearly needed. The World Health Organisation (WHO) recommends the use of artemisinin combination therapy (ACT) in regions where antimalarial drug resistance is emerging. Artemisinin derivatives have been shown to be safe and effective against both drug resistant falciparum and vivax malaria. Current national recommendations advocate the use of a combination of artesunate and amodiaquine, although alternative regimens, such as artemether-lumefantrine and dihydroartemisinin-piperaquine are also available. Further studies are in progress to determine the relative efficacy of these new combination therapies.

\section{Acknowledgements}

We are grateful to the staff of PT Freeport Indonesia Public Health \& Malaria Control Department, International SOS and Lembarga Pengembangan Masyarakat Amungme Kamoro (LPMAK) for support and technical assistance. We also thank Dr Maurits Obeseray, Rosmini, Buhari, Kim Piera and Surinder Kaul for their support and technical assistance. Cross 
checking of all slides was carried out by Ferryanto Chalfein (Timika) and Budi Prasetyorini (NIHRD, Jakarta). We also thank Pascal Ringwald (WHO) for assistance securing amodiaquine tablets. The study was funded by the Wellcome Trust-NHRMC (Wellcome Trust ICRG GR071614MA-NHMRC ICRG ID 283321).

\section{REFERENCES}

1. Tjitra E. Improving the diagnosis and treatment of malaria in Eastern Indonesia [Doctor of Philosophy]: Northern Territory University; 2001.

2. Harinasuta T, Suntharasamai P, Viravan C. Chloroquineresistant falciparum malaria in Thailand. Lancet 1965; 7414:657-60.

3. Young MD, Contacos PG, Stitcher JE, Millar JW. Drug Resistance in Plasmodium Falciparum from Thailand. Am J Trop Med Hyg 1963;12:305-14.

4. Dondero TJ, Jr., Kosin E, Parsons RE, Tann G, Lumanuaw FH. Preliminary survey for chloroquine resistant malaria in parts of North Sumatra, Indonesia. Southeast Asian J Trop Med Public Health 1974;5(4):574-8.

5. Pribadi W, Dakung LS, Gandahusada S, Daldyono. Chloroquine resistant Plasmodium falciparum infection from Lampung and South Sumatra, Indonesia. Southeast Asian J Trop Med Public Health 1981;12(1):69-73.

6. Smrkovski LL, Hoffman SL, Purnomo, Hussein RP, Masbar S, Kurniawan L. Chloroquine resistant Plasmodium falciparum on the island of Flores, Indonesia. Trans R Soc Trop Med Hyg. 1983;77(4):459-62.

7. Maguire JD, Sumawinata IW, Masbar S, Laksana B, Prodjodipuro P, Susanti I, et al. Chloroquine-resistant Plasmodium malariae in south Sumatra, Indonesia. Lancet. 2002;360(9326):58-60.

8. Sumawinata IW, Bernadeta, Leksana B, Sutamihardja A, Purnomo, Subianto B, et al. Very high risk of therapeutic failure with chloroquine for uncomplicated Plasmodium falciparum and P. vivax malaria in Indonesian Papua. Am J Trop Med Hyg 2003;68(4):416-20.
9. Tjitra E, Baker J, Suprianto S, Cheng Q, Anstey NM. Therapeutic efficacies of artesunate-sulfadoxine-pyrimethamine and chloroquine-sulfadoxine-pyrimethamine in vivax malaria pilot studies: relationship to Plasmodium vivax dhfr mutations. Antimicrob Agents Chemother. 2002;46(12):3947-53.

10. Taylor WR, Widjaja H, Richie TL, Basri H, Ohrt C, Tjitra, et al. Chloroquine/doxycycline combination versus chloroquine alone, and doxycycline alone for the treatment of Plasmodium falciparum and Plasmodium vivax malaria in northeastern Irian Jaya, Indonesia. Am J Trop Med Hyg. 2001;64(5-6):223-8.

11. Baird JK, Basri H, Purnomo, Bangs MJ, Subianto B, Patchen LC, et al. Resistance to chloroquine by Plasmodium vivax in Irian Jaya, Indonesia. Am J Trop Med Hyg. 1991;44(5):547-52.

12. Baird JK, Sustriayu Nalim MF, Basri H, Masbar S, Leksana B, Tjitra E, et al. Survey of resistance to chloroquine by Plasmodium vivax in Indonesia. Trans R Soc Trop Med Hyg. 1996;90(4):409-11.

13. Pribadi W, Sutanto I, Atmosoedjono S, Rasidi R, Surya LK, Susanto L. Malaria situation in several villages around Timika, south central Irian Jaya, Indonesia. Southeast Asian J Trop Med Public Health. 1998;29(2):228-35.

14. Lee VH, Atmosoedjono S, Aep S, Swaine CD. Vector studies and epidemiology of malaria in Irian Jaya, Indonesia. Southeast Asian J Trop Med Public Health. 1980;11(3):341-7.

15. WHO. Assessment and monitoring of antimalarial drug efficacy for the treatment of uncomplicated falciparum malaria: WHO; 2003. Report No.: WHO/HTM/2003.50.2003.

16. WHO Expert Committee on Malaria. World Health Organ Tech Rep Ser. 2000;892:i-v, 1-74.

17. Baird JK. Chloroquine resistance in Plasmodium vivax. Antimicrob Agents Chemother. 2004;48(11):4075-83.

18. Brockman A, Paul RE, Anderson TJ, Hackford I, Phaiphun L, Looareesuwan S, et al. Application of genetic markers to the identification of recrudescent Plasmodium falciparum infections on the northwestern border of Thailand. Am J Trop Med Hyg. 1999;60(1):14-21.

19. Baird JK LB, Masbar S, et al. Whole blood chloroquine concentrations with Plasmodium vivax infection in Irian Jaya, Indonesia. Am J Trop Med Hyg 1997;56(6):618-20. 
